\title{
Total mercury in the water column near the shelf edge of the European continental margin
}

\author{
Daniel Cossa $^{a_{*},}$ Marie-Hélène Cotté-Krief ${ }^{b}$, Robert P. Mason $^{c}$ and J. Bretaudeau-Sanjuan ${ }^{a}$ \\ ${ }^{a}$ Institut français de recherche pour l'Exploitation durable de la mer (Ifremer), Centre de Nantes, BP 21105, \\ F.44311, Nantes cedex 03, France \\ ${ }^{\mathrm{b}}$ Institut de biogéochimie marine, Ecole Normale Supérieure, F.92120 Montrouge, France \\ ${ }^{c}$ Chesapeake biological laboratory, University of Maryland, POB 38, Solomons, MD 20688, USA \\ *dcossa@ifremer.fr Tel.: +33-2-40-37-41-76; fax: +33-2-40-37-40-75.
}

\begin{abstract}
The purpose of this paper is to investigate the distribution and the relative importance of processes that affect mercury distribution in the water column at the shelf edge of the Celtic Sea, on the western European continental margin. The water column, down to $4500 \mathrm{~m}$, was sampled during two cruises, one in winter 1994 and the other in June 1995, on eight stations. Total mercury concentrations ranged from 0.29 to $9.37 \mathrm{pM}$ with the extreme values in the first $200 \mathrm{~m}$. The highly variable concentrations in the surface layers are attributed to intense atmospheric-sea water exchange processes. The low concentrations encountered in the shelf water prelude any significant influence of continental waters in this area. In the mixed layer, biological uptake and regenerative processes appear to dominate in controlling the vertical mercury distribution. The intermediate and deep-water mercury distribution is mainly governed by the hydrographic features. In summer, a mercury enrichment was observed in the upwelling zone of the shelf break. Mean mercury concentration in the Lower Deep Water (LDW) was typically $1.96 \pm 0.23 \mathrm{pM}$ and in the Labrador Sea Water (LSW) $1.97 \pm 0.63 \mathrm{pM}$. The Mediterranean Intermediate Water (MIW) revealed similar levels, with a mean mercury concentration of $2.04 \pm 0.84 \mathrm{pM}$. Between LDW and LSW, the Iceland-Scotland Overflow Water (SOW) exhibited higher concentrations $(2.76 \pm 0.35 \mathrm{pM})$. The upper part of the North East Atlantic Central Water (NEADW) and lower part of the North Atlantic Deep Water (NEACW) were characterized by marked peaks of concentration, which are interpreted in term of atmospheric influence and particle regeneration.
\end{abstract}

Keywords: Mercury; Continental margin; Shelf break; Celtic Sea; Atlantic ocean; Upwelling; Deep profile; Atmospheric deposition; Regeneration 


\section{Introduction}

Continental shelves and slopes are essentially biogeochemical interfaces as they link two major aqueous systems, the nearshore waters and the oceans. Their importance has been recognized not only for the global carbon cycle but also for nutrients and trace elements (e.g., Wollast, 2003; Cotté-Krief et al., 2002). Although most of trace elements concentrations in coastal and shelf waters do not appear to differ widely from the open ocean waters, various studies have show local enrichments in the margin surface waters. A variety of sources have been considered to explain trace metal coastal enrichments, including river inputs, atmospheric deposition, sediment diagenesis and upwelling (e.g., Martin and Thomas, 1994). Even in the absence of obvious concentration enrichments, mass-balance approaches have often demonstrated that budgets for certain elements in the ocean margins require external inputs from the open sea (e.g., Tusseau-Villemin et al., 1998; Martin and Thomas, 1994). The same explanation has been advanced for mercury. In coastal waters and enclosed seas, Cossa et al. (1994 and 1996) and Coquery and Cossa (1995) showed mercury enrichments in near shore waters. Furthermore, in the St. Lawrence estuary and gulf, it was concluded that the coastal sediment was the main repository for mercury derived from riverine sources and from direct atmospheric deposition (Cossa and Gobeil, 2000). In addition, the same authors suggest that an oceanic source for sedimentary mercury could not be ruled out. A tentative mass balance calculation for mercury at the ocean margins (Cossa et al., 1996) which concluded that the ocean, via upwelling, may contribute to the mercury load of the coastal waters. However, the data available to support these assertions were scarce, especially mercury distribution profiles in the water column near the shelf edge. We sampled the Celtic region slope waters in order to determine to what extent (i) hydrography (advection from external sources, upwelling), (ii) seston sorption and in situ regeneration, and (iii) deep scavenging determine the mercury distribution in the water column in such regions.

This study was part of the OMEX project (Ocean Margin Exchange, a MAST Program from the European Union) that aimed to examine the land-ocean exchange processes along the western European shelf edge (Wollast and Chou, 2001; http://www.pol.ac.uk/bodc/omex/omex.html). In the framework of this project, Le Gall et al. (1999) and Cotté-Krief et al. (2002) have considered other trace metal distributions in the investigated area but results for mercury have not been published.

\section{Hydrography of the study area.}

The study area (Fig. 1) is part of the European continental margin and includes the wide continental shelf of the Celtic Sea (more than $300 \mathrm{~km}$ wide) and the continental slope down to 
the abyssal plain at $4500 \mathrm{~m}$ depth. The hydrography of the Northeast Atlantic Ocean has been thoroughly described by Mc Cartney (1992), Tsuchiya et al. (1992) and van Aken and Becker (1996). The hydrography across the Celtic Sea shelf edge region $\left(47-50^{\circ} \mathrm{N} ; 7-13^{\circ} \mathrm{W}\right)$ is quite similar.

Figure 1: OMEX study area at the shelf edge of the Celtic Sea and sampling stations. (•) stations sampled during CD 84 cruise in January 1994; ( $\square$ ) stations sampled during CD 94 cruise in June 1995.

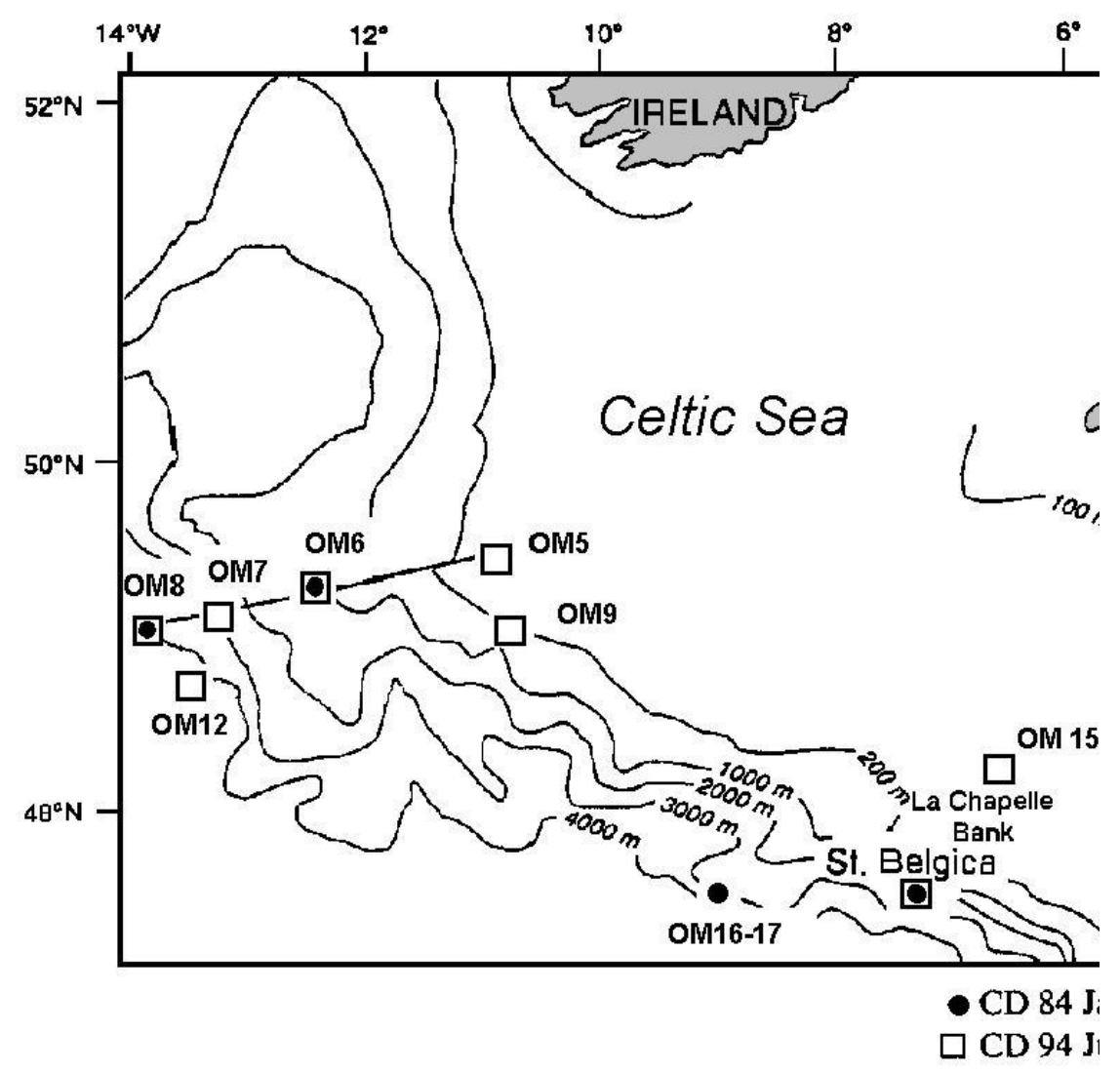

\subsection{Water masses}

T-S plots (Fig. 2A) were used to identify water masses. The surface waters are characterized by summer stratification that includes the surface mixed layer $(0-30 \mathrm{~m})$ and the seasonal thermocline (30-100 m) (Fig. 2B). In winter, the surface mixed layer extends down to the permanent thermocline at $300-400 \mathrm{~m}$ depth. Below the surface waters are the waters associated with the permanent thermocline, the North East Atlantic Central Waters (NEACW), that extend to 500-700 $\mathrm{m}$, indicated by a local salinity minimum in the TS profiles (Fig. 2A). The NEACW results from the advection and mixing of the Sub-Polar Mode Water (SPMW) formed by winter deep convection in the northern North Atlantic (McCartney, 1992; Tsuchiya et al., 1992). 
The large salinity maximum at $850-1000 \mathrm{~m}$ depth corresponds to the Mediterranean Intermediate Waters (MIW), originating from the deep Mediterranean Outflow Water (MOW) at Gibraltar. The depth and the intensity of this salinity maximum show little latitudinal trend in our study area (Fig. 2A), but variations are of greater amplitude at a larger scale (Measures et al., 1995).

Between approximately 1250 and $3000 \mathrm{~m}$ is the North East Atlantic Deep Water (NEADW), which includes the MIW, the Labrador Sea Water (LSW) and the IcelandScotland Overflow Water (ISOW) (McCartney, 1992). The LSW is recognized by a small salinity minimum at 1800-2000 $\mathrm{m}$, and a small salinity maximum identifies the ISOW at $2600 \mathrm{~m}$.

The bottom water is the Lower Deep Water (LDW), and results from the northward advection of the Antarctic Bottom Water (AABW) (McCartney, 1992). 
Figure 2: (A) Temperature-salinity diagrams and water masses (CD 94 cruise, June 1995) in the Celtic slope region. Depth of water masses in brackets expressed in hundreds of meters. (B) Vertical profiles: dissolved oxygen, nitrate and dissolved $\mathrm{Cd}$ and $\mathrm{Pb}$ (CD 94 cruise, June 1995; from Cotté-Krief et al., 2002).
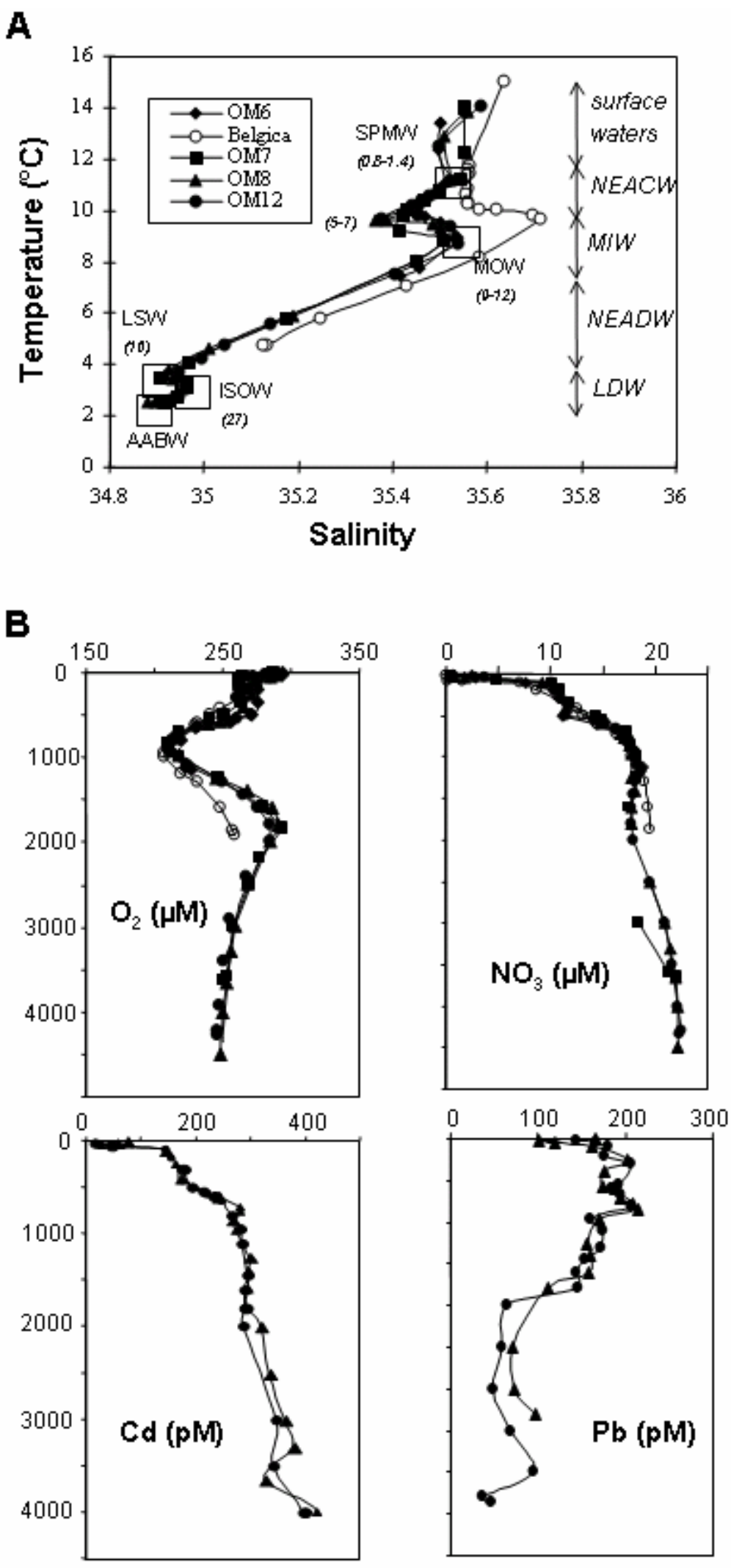


\subsection{Upwelling}

Along the shelf break, a summer surface cooling with a $0.5-1.5^{\circ} \mathrm{C}$ temperature anomaly is observed each year from May to September (Dickson et al., 1980; Pingree et al., 1982). This cooling is associated with high chlorophyll levels (Pingree et al., 1986) and an enhancement of new production (Groom et al., 1997). This seasonal event is the result of deeper water upwelling. The origin of this phenomenon is uncertain (Dickson et al, 1980; Pingree et al, 1982), and the cold waters that mix with the surface waters may originate from below the seasonal thermocline. This mixing is thought to be mostly due to the propagation of exceptionally large internal waves, generated by the interaction of strong barotropic tidal currents with the steep shelf break topography (Dickson et al, 1980; Pingree et al, 1986).

\section{Methodology}

\subsection{Sampling and pre-treatment}

Sampling was carried out in the framework of the OMEX program, jointly with the Southampton Oceanography Centre (SOC, UK) for the trace metals work, in January 1994 (20-31 January, CD-84 cruise) and in June 7-16, 1995 (7-16 June, CD-94 cruise). Vertical profiles were established at stations along two shelf break transects off the Goban Spur zone (stations OM5 to OM12) and on the break near La Chapelle Bank (Stations OM15 and "Belgica") (Fig. 1). Stations OM6, OM8 and station "Belgica" were sampled in winter 1994 and stations OM5, OM6, OM7, OM8, OM9, OM12, OM15 and station "Belgica" were sampled in summer 1995. The summer sampling included shallow stations on the shelf: OM5, OM9 and OM15.

Water samples were taken using 10L Teflon coated Lever Action Niskin bottles fixed on a sampling rosette. Niskin bottles were equipped with Teflon taps and carefully cleaned before use with Decon detergent and acid washes. Hydrographic parameters were obtained using a CTD profiler with an oxygen sensor and a transmissometer. The sampling rosette and CTD were also carefully cleaned, zinc sacrificial electrodes removed, and all exposed corrodible metal parts coated in parafilm, prior to the sampling.

Filtrations were performed under high-purity nitrogen pressure (circa 0.8 bar) in line with the Niskin bottles through acid-washed glass fiber filters (Whatman ${ }^{\circledR} 0.7 \mu \mathrm{m}$ pore size, diameter $47 \mathrm{~mm}$ ) set up on an acid-cleaned polypropylene filter holder, Millipore). Filtrates were acidified to $\mathrm{pH} 1$ with Suprapur ${ }^{\circledR}$ (Merck) $\mathrm{HCl}$ according to Gill and Bruland (1990) and stored in acid washed FEP Teflon bottles inside a plastic bag. Special attention has been devoted to minimizing contamination; all handling of samples was done in a clean container 
under laminar flow benches using ultra-clean techniques described elsewhere (Quémerais and Cossa, 1995).

\subsection{Analyses}

The total mercury measurements were performed according to Gill and Bruland (1990). This method consists to (i) a reduction step of dissolved mercury by a $4 \%$ sodium tetraborohydride solution which converts the mercury $\left(\mathrm{Hg}^{\mathrm{II}}\right)$ to volatile elementary mercury $\left(\mathrm{Hg}^{0}\right)$, (ii) a gas transportation (argon) and a preconcentration step on a gold amalgam trap, (iii) a thermal evolution of $\mathrm{Hg}^{0}$ from the amalgam and (iv) a detection of $\mathrm{Hg}^{0}$ by atomic fluorescence (Merlin, PSA). The detection limit of this procedure, estimated as three times the standard deviation of the blanks, was $0.25 \mathrm{pM}$; the reproducibility was $15 \%$. Quémerais and Cossa (1995) have described the detailed procedure.

\section{Results and discussion}

\subsection{Deep profiles}

Results presented in this section are those of the vertical stations, located across the Celtic slope, stations OM7, OM8, OM12, and station "Belgica" during summer, which corresponds to oligotrophic conditions, and stations OM8 and "Belgica" during winter (Fig. 1).

\subsubsection{Oxygen and nutrients}

The overall oxygen profile is characterized by a small maximum near $500 \mathrm{~m}$ and a distinct minimum near $1000 \mathrm{~m}$ (Fig. 2B). Below, the NEADW is well oxygenated. According to several studies (Tsuchiya et al., 1992; Measures et al., 1995), the oxygen minimum is not linked to the presence of the MIW, despite its appearance in our profiles. It is partly a relict from the extreme oxygen minimum of the productive Northwest African upwelling waters, and its depth does not vary with latitude along the East Atlantic basin whereas the depth of the salinity maximum does.

Below the nutrient-depleted surface waters, nitrate increases in the NEACW (Fig. 2B). A sharp gradient occurs near $500 \mathrm{~m}$ into the oxygen minimum layer. The depth of the oxygen minimum (900-1000 m) corresponds to a nitrate maximum and the core of the LSW (1600$2000 \mathrm{~m}$ ) to a slight nitrate minimum. Concentrations are the highest in bottom waters, up to $23 \mu \mathrm{M}$ for nitrate, $1.4 \mu \mathrm{M}$ for phosphate and $46 \mu \mathrm{M}$ for silicate (Cotté-Krief et al., 2002), reflecting the presence of diluted silicate-rich Antarctic bottom waters (Yeats et al., 1995 and Saager et al., 1997).

\subsubsection{Mercury}


Low concentrations around $2 \mathrm{pM}$ were found below $2000 \mathrm{~m}$ whatever the season (Fig. 3). This concentration level is in good agreement with those (only total mercury data were taken into account) published previously by Mason et al. (1995 and 1998) for the North Atlantic deep waters, south of Iceland and also by earlier measurements by Gill and Fitzgerald (1987) at the slope in the northwest Atlantic. The LDW (bottom water below $4000 \mathrm{~m}$ ) concentrations were typically $1.96 \pm 0.23 \mathrm{pM}$ (mean \pm standard deviation, $\mathrm{n}=5$ ) and the LSW (identified by low salinity and high dissolved oxygen) concentrations were $1.97 \pm 0.63 \mathrm{pM}(\mathrm{n}=5)$. In between, the ISOW (identified by a small salinity peak at $2600 \mathrm{~m}$ ) mercury concentrations were statistically significantly higher, with a mean of $2.76 \pm 0.35 \mathrm{pM}(\mathrm{n}=3)$. The upper part of the NEADW (i.e., the 1200-1500 m layer over the LSW water type) and the lower part of the NEACW (i.e., the 600 to $700 \mathrm{~m}$ layer corresponding to salinity minimum at station OM8 and OM12, Fig. 2A), were characterized by marked peaks of concentration up to $4.49 \mathrm{pM}$ and $5.23 \mathrm{pM}$, respectively (Fig. 3). These three mercury enriched water masses originate from sinking of surface waters "recently" in contact with the atmosphere and with atmospheric inputs, the dominant source of ocean mercury. The ISOW is a mixture of NACW (itself a mixture of LSW and salty surface waters) and polar water which descends the continental slope as a dense gravity current after the sill, the Faeroe Bank Channel between Scotland and Iceland (van Aken and de Boer, 1995; Yeats and Measures, 1998). The NEACW results from the advection of SPMW formed by winter deep convection of the Northern North Atlantic, and the NEADW is formed by sinking of surface waters at high latitudes in the Norwegian Sea with subsequent mixing with LSW. High lead concentrations, a trace element with a strong atmospheric source, were also found in the NEACW and NEADW during the same cruises (Fig. 2B). Thus, the atmospheric source is a reasonable explanation for the high mercury content of these water masses. However, the potential input of mercury due to regeneration of particulate material between 600 and $700 \mathrm{~m}$ cannot be ruled out, since this layer coincides with the increase in nitrate and cadmium concentrations (Fig. 2B). 
Figure 3: Vertical mercury profiles at the shelf edge of the Celtic sea in June 1995 (CD 94 cruise) and January 1994 (CD 84 cruise). (ロ) OM7, (10) OM8, (3) OM12 and (O) station "Belgica".

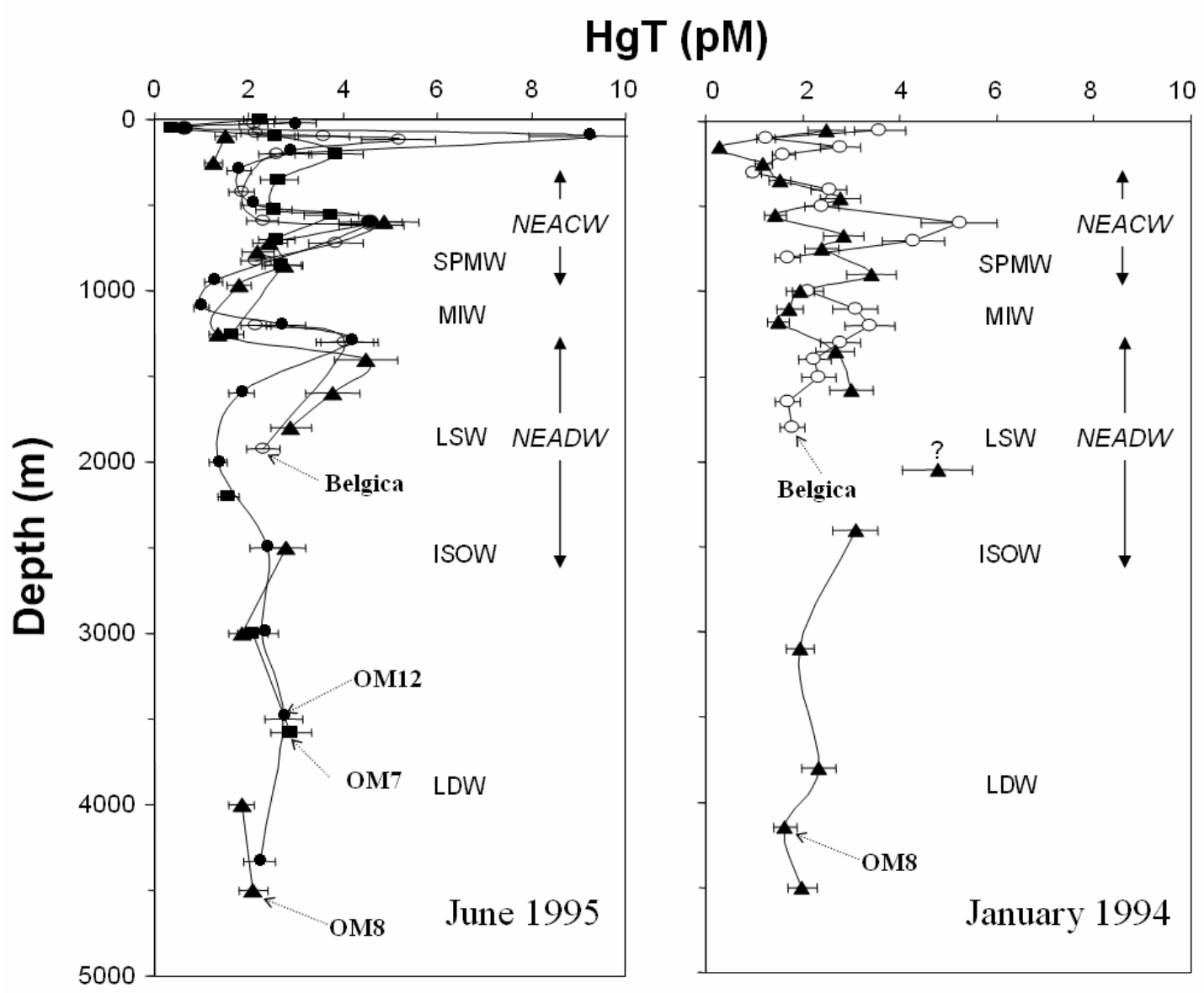

Despite finding similarly elevated mercury and lead concentrations in the NEACW and NEADW, a large difference in the lead and mercury distributions was found in the MIW. While lead concentrations remained high (Fig. 2B) compared to surrounding water masses, mercury levels were relatively low, although variable: the average concentration was $2.04 \pm$ $0.84 \mathrm{pM}(\mathrm{n}=8)$ between 900 and $1100 \mathrm{~m}$ (Fig. 3). It has been established that Mediterranean waters are enriched with lead (Copin-Montegut et al., 1986), but this is not the case for mercury. From our work on total mercury distribution in the Western Mediterranean, the typical concentration of mercury in the MOW at Gibraltar is $2.23 \pm 0.41 \mathrm{pM}$ (Cossa et al., 1997). Moreover, Horvat et al. (2003) published more recently lower concentrations in the deep western Mediterranean waters, 1.72 and $1.93 \mathrm{pM}$ at 1000 and $2780 \mathrm{~m}$ respectively at a station off Corsica in the Algerian basin. However, since the MOW represents only $\sim 6 \%$ of the MIW in this area, the Mediterranean source alone may not account for the low mercury concentrations found associated with the MIW. The chemical characteristics of the Northwest African upwelling waters, which are noticeable around $900 \mathrm{~m}$ from the presence of a 
dissolved oxygen minimum (Tsuchiya et al., 1992; Measures et al., 1995), may contribute to explain the low mercury levels at these depths. More data are required to sort out these various influences.

\subsection{Surface and shelf waters}

\subsubsection{Oxygen and nutrients}

In the summer mixed layer, dissolved oxygen decreases by $5-10 \%$ from the surface to $100 \mathrm{~m}$ depth, while surface or subsurface chlorophyll maxima reach microgram per liter levels (Cotté-Krief et al., 2002). The nitrate concentration distribution shows the usual uptake-regeneration profiles, with discontinuities associated with the hydrographic structure (Fig. 2B). Cotté-Krief et al. (2002) also identified the presence of an upwelling near the shelf break (outcropping near the stations OM5, 6 and 9) by the lower temperature of surface waters detected by satellite imagery.

\subsubsection{Mercury}

Total mercury concentrations ranged from 0.29 to $9.37 \mathrm{pM}$ with the extreme values in the upper $200 \mathrm{~m}$ (Fig. 4). Subsurface peaks were observed between 100 and $200 \mathrm{~m}$ at stations OM6, OM12 and Belgica (Fig. 4), the highest peak concentrations occurring during the summer cruise. These maxima are not located deep enough to result from any effect of the internal tidal resuspension of the shelf break sediments. This type of peak has already been observed in the Bay of Biscay (Cossa et al., 1992), and has been attributed to regeneration processes below the seasonal thermocline. Indeed, a closer observation of the summer mercury concentration distribution reveals low values at $50 \mathrm{~m}$ and a peak around $100 \mathrm{~m}$ (Fig. 4). These features are consistent with a biological uptake and a partial regeneration, as we already observed in the Algerian basin and the Gibraltar strait of the Mediterranean (Cossa et al., 1997). 
Figure 4: Detailed vertical mercury profiles at the shelf edge of the Celtic sea within the first $500 \mathrm{~m}$ in June 1995 (CD 94 cruise) and January 1994 (CD 84 cruise). ( $\square$ ) OM5, ( ) OM6, (ם) OM7, (10) OM8, ( $)$ OM9, (3) OM12, (X) OM15 and (O) station "Belgica".

\section{$\mathrm{Hg}(\mathrm{pM})$}

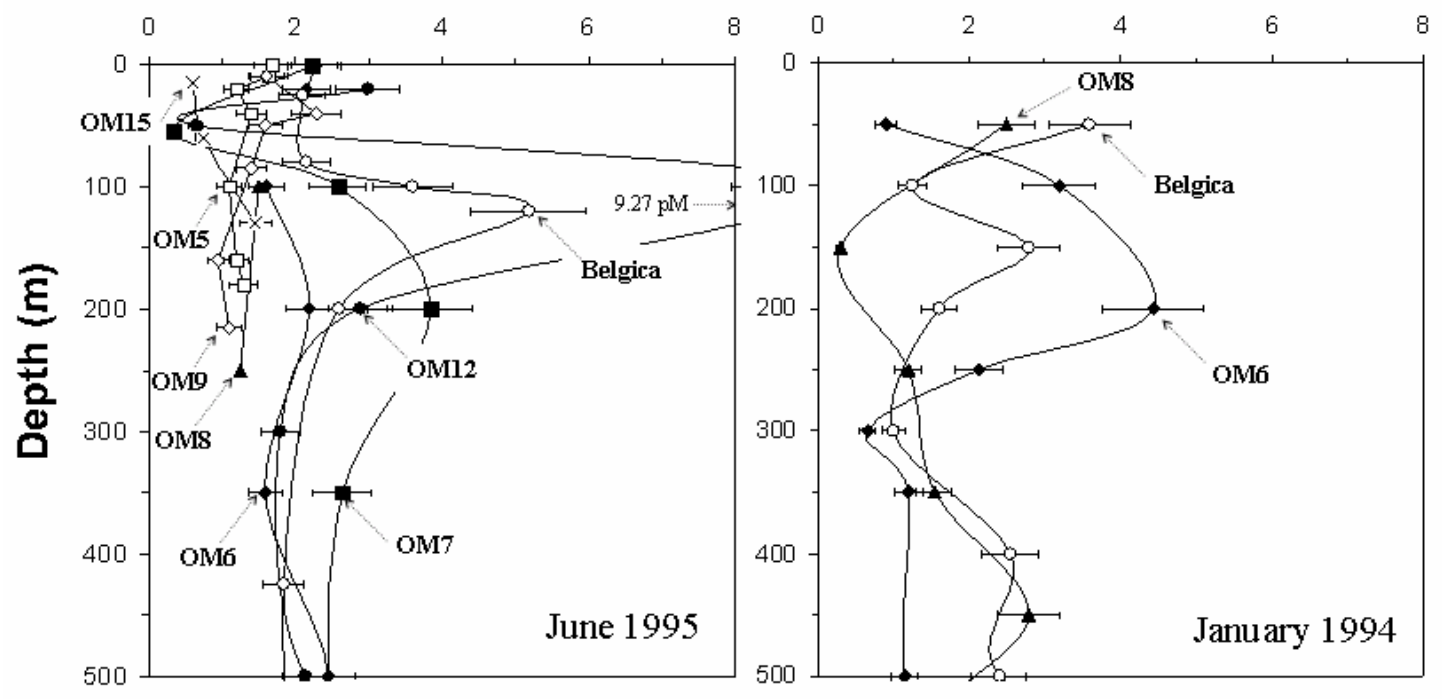

Within the first $50 \mathrm{~m}$ there is a strong variation between 0.60 and $2.50 \mathrm{pM}$ in summer and 0.90 and $3.59 \mathrm{pM}$ in winter (Fig. 4). The highly variable concentrations in surface samples can be attributed to atmospheric deposition input and to the rapid conversion of $\mathrm{Hg}^{\mathrm{II}}$ to $\mathrm{Hg}^{0}$ and its subsequent escape in the atmosphere (Mason et al., 1998).

From the summer cruise, the horizontal and vertical representation of the mercury distribution across the shelf edge transect indicates two main features (Fig. 5): (i) the lowest concentrations in the shelf water column (stations OM15, OM5 and OM9), and (ii) a tongue of high concentrations outcropping around station OM6 (HgT > 2 pM, Fig. 5). 
Figure 5: Mercury isoconcentration distribution (pM) across a longitudinal transect across the Celtic shelf edge in June 1995 (CD 94 cruise).

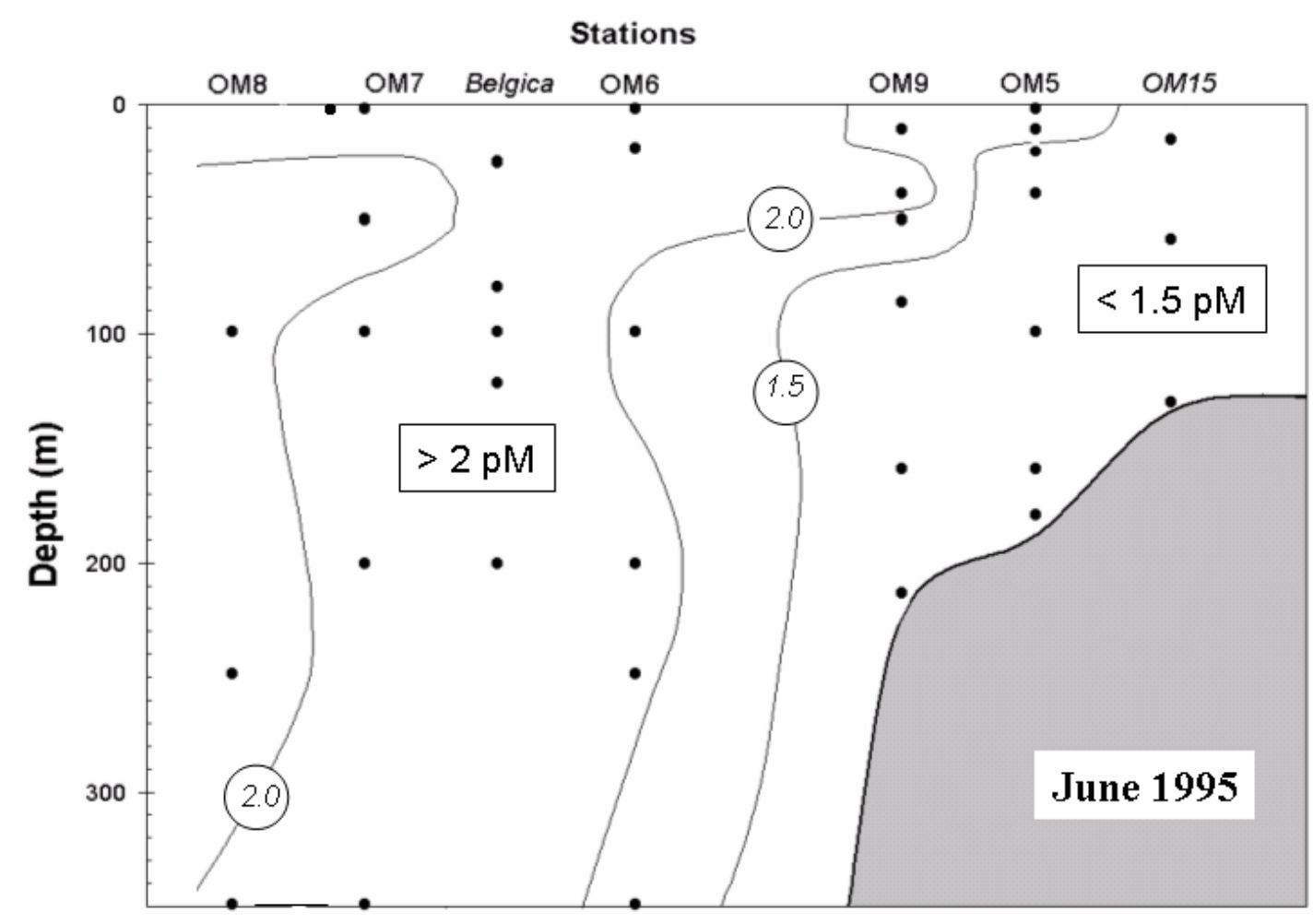

Firstly, the low mercury concentrations level in coastal waters is a consistent with earlies measurements made in the English Channel $(<2.5 \mathrm{pM}$ according to Cossa and Fileman, 1991). This confirms that coastal water mercury enrichment is only a concern for the nearshore zone as we have already discerned for other coastal systems, such as the golfe du Lion in the Western Mediterranean, the North Sea and the St. Lawrence estuary and gulf (Cossa et al., 1996; Cossa et Gobeil, 2000). Mercury, supplied from continental waters through estuaries, is rapidly scavenged by coastal sediments and/or evolved to the atmosphere after reduction (Cossa and Gobeil, 2000; Rolfhus and Fitzgerald, 2001; Laurier et al., 2003).

Secondly, the tongue of mercury enriched waters presents a core centered on the shelf break outcropping near the stations where Cotté-Krief et al. (2002) detected the presence of an upwelling (OM5, 6 and 9). From comparison between summer and winter data sets, the same authors pointed out that nitrate and cadmium profiles were enriched by at least a factor of 2 in the cold surface layer above the seasonal thermocline. Similar comparison cannot be made for mercury due to the lack of data in winter conditions. However, it is interesting to note that Mason and Fitzgerald (1993) observed high mercury concentrations in the thermocline waters of the equatorial Pacific and suggested that upwelling was a substantial 
source of mercury to the productive surface waters. Pending the confirmation of this feature, an upwelling source for mercury into the Celtic Sea margin remains an hypothesis.

\section{Conclusions}

Mercury concentrations near the shelf edge of the Celtic Sea are quite similar to profiles in the open NorthEast Atlantic. With the exception of a possible upwelling influence, the concentrations at the surface are not enriched compared to the nearby open ocean. Moreover, the lowest concentrations were encountered in the shelf water column. Continental influence from rivers does not reach this area probably due to sedimentation and atmospheric recycling occurring in estuaries and other nearshore areas.

The vertical profiles confirm that the deep Atlantic waters have mercury levels around 2 pM in accordance with previous studies (e.g., Mason et al., 1998) and show that MIW mercury concentrations are similar. As found in the Pacific Ocean (Laurier et al., this volume), the profiles pattern suggest the existence of an atmospheric signature: the parts of NEACW and NADW, which consist of water masses previously in contact with the atmosphere, present high mercury concentrations. In addition, regenerative processes seem also to contribute to the mercury distribution at least within the surface waters and down to the seasonal thermocline. The biological and chemical controls of biological uptake and remineralization and photoreduction reasonably explain the high variability of the surface and sub-surface waters.

The absence of any information on the speciation of mercury precludes any further interpretation of the present results in terms of biogeochemical cycling for this element. Further research is needed on this topic at the ocean margins, which are particularly dynamic areas. 
Acknowledgments -We would like to thank the OMEX community for sharing the data and particularly Tom Treacy and Michael Orren (University of Galway), Thomas Raabe and Uwe Brockmann (University of Hamburg) for nutrient data, Peter Statham (Southampton Oceanographic Centre) for hydrological parameters. We thank the officers and crew of the RRS Charles Darwin for their assistance at sea. Thanks are also due to Peter Statham for his helpful comments on the manuscript. This research was sponsored by an OMEX EU contract (\# MAS2-CT93-0069). 


\section{References}

Copin-Montégut, G., Courau, P., Nicolas, E., 1986. Distribution and transfer of trace elements in the Western Mediterranean. Mar. Chem. 18, 189-195.

Coquery, M., Cossa, D., 1995. Mercury Speciation in Surface Waters of the North Sea. Neth. J. Sea Res. 34, 245-257.

Cossa, D., Gobeil, C., 2000. Mercury Speciation in the Lower St. Lawrence Estuary. Can. J. Fish. Aquat. Sci. 57: 138-147.

Cossa, D., Martin, J.-M., Takayanagi, K., Sanjuan, J., 1997. The Distribution and Cycling of Mercury in the Western Mediterranean. Deep Sea Res. 44, 721-740.

Cossa, D., Coquery, M., Gobeil, C., Martin, J.-M., 1996. Mercury Fluxes at the Ocean Margins. 229-247. In: Regional and Global Cycles of Mercury: Sources, Fluxes, and Mass Balances. W. Baeyens, R. Ebinghaus and O. Vasiliev editors. Kluwer Academic Publishers, Dordrecht, The Netherlands.

Cossa D., Sanjuan, J., Noël, J., 1994. Mercury Transport in the Waters of the Strait of Dover. Mar. Poll. Bull. 28, 385-3894.

Cossa, D., Michel, P., Noël, J., Auger, D., 1992. Vertical profile of total mercury in relation to arsenic, cadmium and copper distributions at the Eastern North Atlantic ICES reference station $\left(46^{\circ} \mathrm{N} ; 6^{\circ} \mathrm{W}\right)$. Oceanol. Acta $15,603-608$.

Cossa, D., Fileman, C., 1991. Mercury concentrations in surface waters of the English Channel : A cooperative study. Mar. Pollut. Bull. 22, 197-200.

Cotté-Krief, M.-H., Thomas, A. J., Martin, J.-M., 2002. Trace metal (Cd, $\mathrm{Cu}, \mathrm{Ni}$ and $\mathrm{Pb}$ ) cycling in the upper water column near the shelf edge of the European continental margin (Celtic Sea). Mar. Chem. 79, 1-26.

Dickson, R.R., Gurbutt, P.A.., Pillai, V.N., 1980. Satellite evidence of enhanced upwelling along the European continental slope. J. Phys. Oceanogr. 10, 813-819.

Gill, G.A. and Fitzgerald, W.F. 1988. Vertical mercury distribution in the oceans. Geochim. Cosmochim. Acta 52, 1719-1728.

Gill, G. A., Bruland, K. W., 1990. Mercury speciation in surfacefrsehwater systems in California and other areas. Environ. Sci. Technol. 24, 1392-1399.

Groom, S., Woomfenden, J., Joint, I., 1997. Remote sensing of primary production and new production at the Celtic Sea continental shelf break. In: 3rd EU Conference Exchange Processes at the Continental/Ocean margins in the North Atlantic (Vigo, Spain). 
Horvat, M., Kotnik, J., Fajon, V., Zvonaric, T., and Pirrone, N., 2003. Speciation of mercury in surface and deep-sea waters in the Mediterranean Sea. Atmos. Environ. 37, S93-108.

Laurier, F.J.G., Cossa, D., Gonzalez, J.-L., Breviere, E., Sarazin, G., 2003. Mercury transformations and exchanges in a high turbidity estuary: the role of organic matter and amorphous oxyhydroxides. Geochim. Cosmochim. Acta 67, 3329-3345.

Laurier, F.J.G., Mason, R.P., Gill, G. and Whalin, L., 2004. Mercury distribution in the Pacific Ocean- Twenty years of observations. Mar. Chem. (this volume).

Le Gall, C.-C., Statham, P.J., Morley, N.H., Hydes, D.J., Hunt, C.H., 1999. Processes influencing distributions and concentrations of $\mathrm{Cd}, \mathrm{Cu}, \mathrm{Ni}$ and $\mathrm{Mn}$ at the North West European shelf break. Mar. Chem. 68, 97-115..

Martin, J.-M., Thomas, A.J., 1994. The global insignificance of telluric input of dissolved trace metals $(\mathrm{Cd}, \mathrm{Cu}, \mathrm{Ni}$ and zn) to ocean margins. Mar. Chem. 46, 165-178.

Mason, R.P., Rolfhus, K.R., Fitzgerald, W.F., 1998. Mercury in the North Atlantic. Mar. Chem. $61,37-53$.

Mason, R.P., Rolfhus, K.R., Fitzgerald, W.F., 1995. Methylated and elemental mercury in the surface and deep ocean waters of the North Atlantic. Water Air Soil Pollut. 80, 665-677.

Mason, R.P., Fitzgerald, W.F., 1993. The distribution and biogeochemical cycling of mercury in the equatorial Pacific Ocean. Deep-Sea Res. 40, 1897-1907.

McCartney, M.S., 1992. Recirculating components to the deep boundary current of the northern North Atlantic. Progr. Oceanogr. 29, 283-383.

Measures, C.I., Yeats, P.A., Schmidt, D., 1995. The hydrographic setting of the IOC baseline cruise to the eastern Atlantic $30^{\circ} \mathrm{S}$ to $35^{\circ} \mathrm{N}$. Mar. Chem. 49, 243-252.

Pingree, R.D., Mardell, G.T., Holligan, P.M., Griffiths, D.K., Smithers, J., 1982. Celtic sea and Armorican current structure and the vertical distributions of temperature and chlorophyll. Cont. Shelf Res. 1, 99-116.

Pingree, R.D., Mardell, G.T., New, A.L., 1986. Propagation of internal tides from the upper slopes of the Bay of Biscay. Nature 321, 154-158.

Quemerais, B., Cossa, D., 1995. Protocoles d'échantillonnage et d'analyse du mercure dans les eaux naturelles. Environnement canada - région du Québec, Centre Saint-Laurent. Rapport scientifique et technique ST-31,39p.

Rolfhus, K.R., Fitzgerald, W.F., 2001. The evasion and spatial/temporal distribution of mercury species in Long Island Sound, CT-NY. Geochim. Cosmochim. Acta 65, 407-418. 
Saager, P.M., de Baar, H.J.W., de Jong, J.T.M., Nolting, R.F., Schijf, J., 1997. Hydrography and local sources of dissolved trace metals $\mathrm{Mn}, \mathrm{Ni}, \mathrm{Cu}$, and $\mathrm{Cd}$ in the northeast Atlantic Ocean. Marine Chemistry 57, 195-216.

Sournia, A., Brylinski, J.-M., Dallot, S., Le Corre, P., Leveau, M., Prieur, L., Froget, 1990. Fronts hydrologiques au large des côtes françaises: Les sites-ateliers du programme Frontal. Oceanol. Acta 13, 413-438.

Tsuchiya, M., Talley, L.D., McCartney, M.S., 1992. An eastern Atlantic section from Iceland southward across the equator. Deep-Sea Res. 39, 1885-1917.

Tusseau-Vuillemin, M.-H., Mortier, L., Herbaut, C., 1998. Modeling nitrate fluxes in an open coastal environment (Gulf of Lions); transport versus biogeochemical processes, J. Geophy. Res., C, Oceans 103, 7693-7708.

van Aken, H. M., de Boer, C. J., 1995. On a synoptic hydrography of intermediate and deep waters masses in the Iceland basin. Deep-Sea Res. 42, 165-189.

van Aken, H. M., Becker, G, 1996. Hydrography and through-flow in the north-eastern North Atlantic Ocean: the NANSEN project. Progr. Oceanogr. 38, 297-346.

Wollast, R., 2003. Continental Margins - Review of Geochemical Settings. pp. 15-31. In: Ocean Margin Systems. G. Wefer et al. editors. Springer, Berlin, 495p.

Wollast, R., Lei Chou, 2001. Ocean Margin Exchange in the Northern Gulf of Biscay: OMEX I. An introduction. Deep Sea Res. II, 48, 2971-2978.

Yeats, P.A., Westerlund, S., Flegal, A.R., 1995. Cadmium, copper and nickel distributions at four stations in the eastern central and south Atlantic. Mar. Chem. 49, 283-293.

Yeats, P.A., Measures, C.I., 1998. The hydrographic settings of the second IOC contaminants baseline cruise. Mar. Chem. 61, 3-14. 